\title{
АТС "ИНДУСТРИЯ 4.0": ОСНОВЫ ЧИСЛОВОГО ПРОГРАММНОГО УПРАВЛЕНИЯ
}

\section{ATC INDUSTRY 4.0: BASICS OF COMPUTER NUMERICAL CONTROL}

\begin{abstract}
И.В.Яминский $, 2,3$, д.ф.-м.н., проф. МГУ имени М.В.Ломоносова физического и химического факультетов, генеральный директор Центра перспективных технологий, директор Энергоэффективных технологий (ORCID: 0000-0001-8731-3947), А.И.Ахметова 1, 2, 3, инженер НИИ ФХБ имени А.Н.Белозерского МГУ, ведущий специалист Центра перспективных технологий и Энергоэффективных технологий (ORCID: 0000-0001-6363-8202) / yaminsky@nanoscopy.ru I.V.Yaminskiy', 2, 3, Doctor of Sc. (Physics and Mathematics), Prof. of Lomonosov Moscow State University, Physical and Chemical departments, Director of Advanced Technologies Center, Director of Energy Efficient Technologies, A.I.Akhmetova 1, 2,3, Engineer of A.N. Belozersky Institute of Physico-Chemical Biology, Leading Specialist of Advanced Technologies Center and of Energy Efficient Technologies
\end{abstract}

DOI: 10.22184/1993-8578.2019.12.6.366.369

Получено: 09.09.2019 г.

Разработки в области станкостроения с числовым программным управлением становятся все более востребованными и прогрессивными. От обычного трехкоординатного станка мы перешли к созданию высокопрецизионных станков и станков с автосменой инструмента. Запросы рынка требуют постоянного совершенствования инструментальной базы и программного управления. The developments in the field of machine tools industry with computer numeric control (CNC) become more and more popular and advanced. From a conventional three-coordinate machine, we proceeded to creation of high-precision machines and machines with automatic tool change. Market demands require continuous improvement of the instrumental base and program management.

B этой статье мы приводим поэтапное описание работы на станке с автосменой инструмента АТC "Индустрия 4.0" (рис.1).

Числовое программное управление (ЧПУ) осуществляет автоматическое управление приводами и узлами станка по заданной управляющей программе. Обычно такие программы составлены на специализированном языке программирования - G-код. Они представляют собой последовательность команд выполнения простейших операций на станке.

Для автоматизации создания управляющих программ для ЧПУ по готовым 3D-моделям применяются автоматизированные системы технологической подготовки производства (АСТПП) или САМ-системы. Они позволяют смоделировать процесс обработки детали на ПК. Мы используем САMсистему HSMXpress.
В процессе моделирования обработки вначале задаются параметры заготовки, из которой будет изготовлена деталь. На заготовке определяется начальная точка, по которой осуществляется привязка к координатам станка. Затем для отдельных элементов модели, таких как паз, карман, группа отверстий и т.д. создаются операции. Для каждой операции определяется инструмент и рабочие параметры. Инструмент может быть взят из базы данных, соответствующей реальному набору инструментов в корзине станка. На рис.2 изображен инструментальный магазин станка АТС "Индустрия 4.0".

После определения всех операций генерируются траектории движения инструментов. В САМсистеме можно симулировать обработку заготовки и сравнить получившийся результат с исходной 3D-моделью (рис.3). 


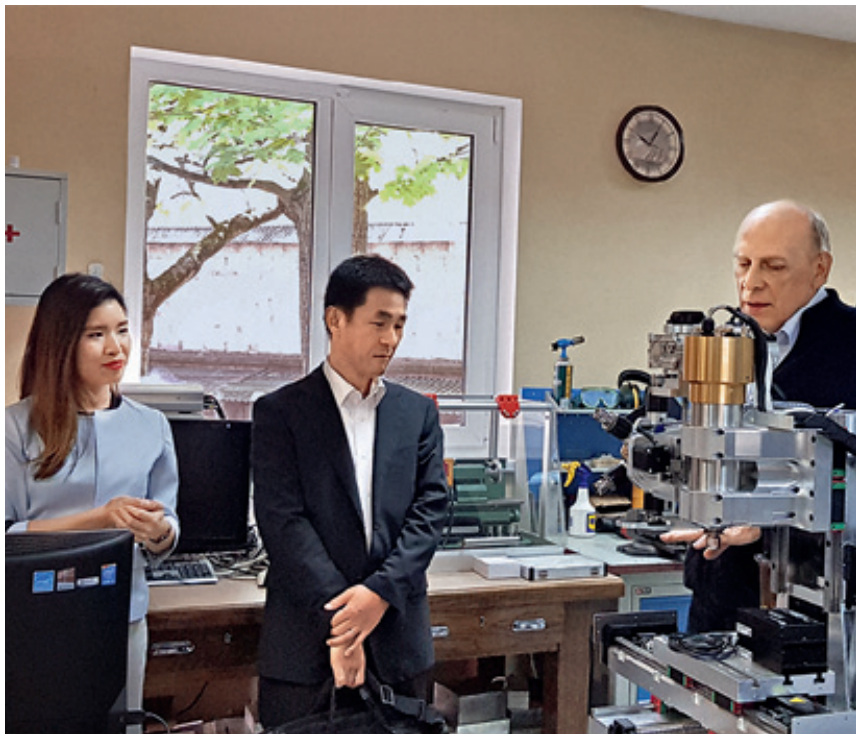

Puc.1. Демонстрация работы станка АТС "Индустрия 4.0" японской делегации

Fig.1. Presentation of ATC Industry 4.0 machinery operation to a Japanese delegation

После отладки работы программы по компьютерной симуляции она переводится в понятные ЧПУ коды. Этот процесс называется постпроцессированием. Постпроцессор учитывает особенности ЧПУ для конкретной модели станка.

Перед изготовлением в станок необходимо установить инструменты, выбранные для изготовления

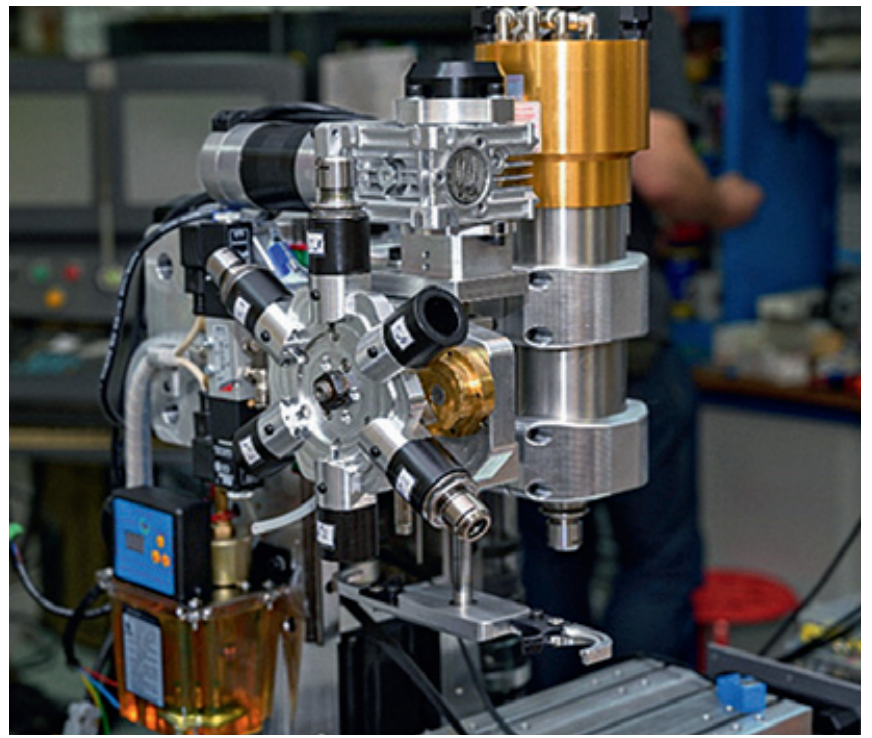

Pис.2. Инструментальный магазин станка АТС "Индустрия 4.0"

Fig.2. ATC Industry 4.0 machinery basket

детали. Обычно станок имеет определенный набор инструментов, подходящий для изготовления всех деталей изделия. Режимы резания зависят от материала заготовки и определяют качество получаемой поверхности. Инструменты хранятся в барабане и автоматически устанавливаются в шпиндель станка в соответствии с выполняемой программой.
$\mathbf{T}$ his paper describes working stages on the ATC Industry 4.0 machine with automatic changing of tools (see Fig.1).

The computer numerical control (CNC) provides for automatic control of drives and machine units according to the loaded control program. Usually, control programs are written in a special programming language called $\mathrm{G}$-code. This code is a sequence of commands to perform simple operations by the machine.

Automatic systems for technological preparation of production (ASTPP) or computer-aided manufacturing (CAM-systems) are used to develop a CNC control software according to ready-touse 3D models.

These systems are intended for parts treatment process simulation on a PC. We use HSMXpress CAM-system in our work.

Blank parameters that is used to produce an item are specified initially during the simulation processing. The initial point to set the coordinate grid of the machinery is placed onto the blank. After this the operations to produce separate elements of the model, such as a groove, pocket, group of holes and others are to be developed. The tools and operating parameters of every operation are to be determined. Tools are chosen from a database which corresponds to the real tool set in the machinery basket. Fig.2 shows the tool set of ATC Industry 4.0 machinery.

The tool motion paths are generated after setting of all operations. CAM-system permits to simulate a blank machining and to compare the result with the original 3D model (see Fig.3).

On completion of the simulation program it is transformed into the $\mathrm{CNC}$ codes. This process is called postprocessing. The postprocessor takes into account the CNC features for a specific machine tool model.

It is necessary to set the tools into the machine which were chosen to produce the detail. As a rule, the machinery has certain 


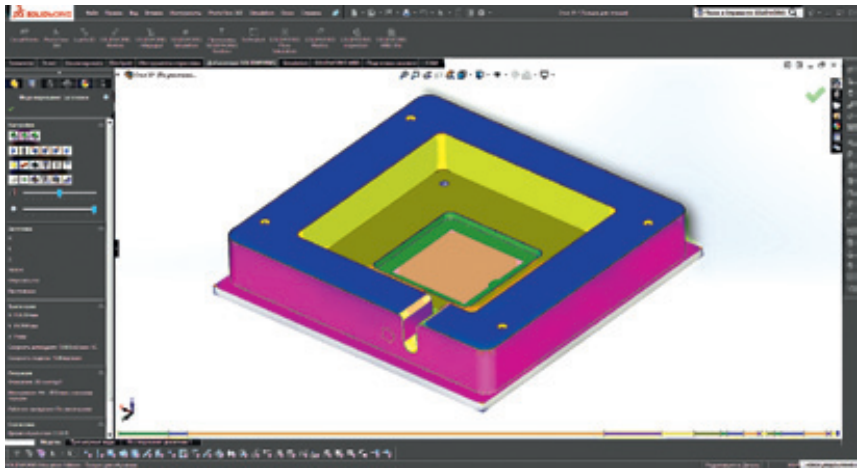

Рис.3. Симуляция процесса изготовления детали в программе SolidWorks. Время обработки в программе симуляции займет 38 мин $5 \mathrm{c}$

Fig.3. Simulation of a detail manufacturing process in SolidWorks software. Machining time simulation takes about $38 \mathrm{~min} 5 \mathrm{sec}$

Каждый инструмент должен быть откалиброван по координате $Z$ относительно общей реперной точки.

Заготовка устанавливается в тиски или другое зажимное устройство, расположенное на столе станка. Стол осуществляет подачу заготовки в плоскости XY. Для определения соответствия между системой координат станка и начальной точкой, выбранной в САМ-системе, необходимо выполнить привязку заготовки к координатам станка. Для более точной привязки используется специальный инструмент, называемый 3D-индикатором. Он позволяет с точностью 0,01 мм определить положение заготовки в координатной системе станка. Далее запускается процесс изготовления изделия.

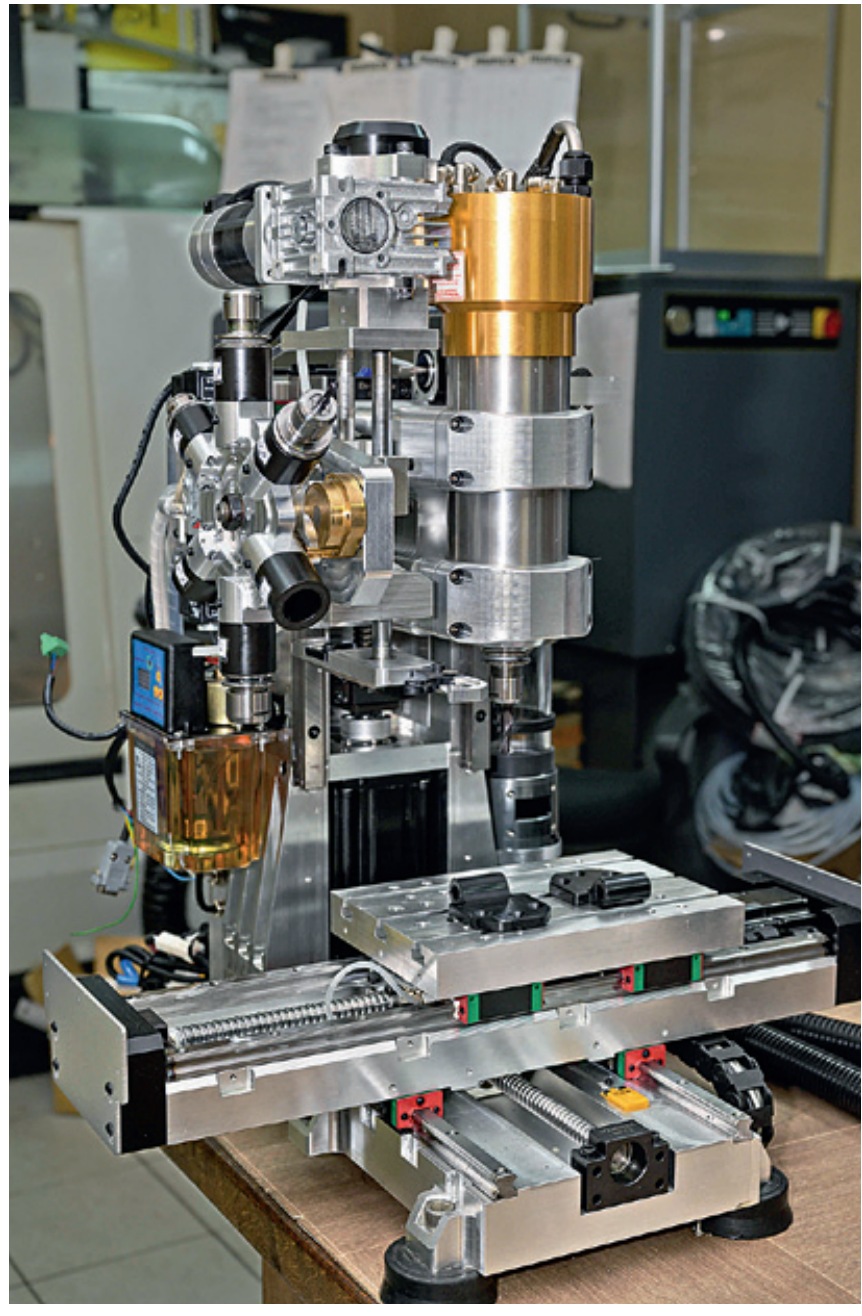

Puc.4. Обрабатывающий центр АТС "Индустрия 4.0" Fig.4. ATC Industry 4.0 machining center tools suitable for manufacturing all details the product. The cutting modes depend on the blank material and determine quality of the surface to be obtained. Tools are stored in a basket and are automatically set into the machinery spindle in accordance with the loaded program. Every tool must be calibrated in the $\mathrm{Z}$ coordinate relatively to the common check point.

The blank is installed into the clutches or other fixing device mounted on the table surface. The table moves the blank in the XY plane. The blank position should be bound with the machinery coordinates system and the checkpoint that was chosen in the CAM-system in order to set the correspondence between the machinery coordinates system and the checkpoint. The special instrument called 3D indicator is used to precise the binding. It allows of determining the blank position with accuracy of $0.01 \mathrm{~mm}$ in the machinery coordinate system.

Use of the machine with an auto-change tool ATC Industry 4.0 (see Fig.4) for creating a product prototype or the finished product is greatly simplified, and manual labor is also minimized [1, 2].
The machinery is suitable both for manufacturing and training needs, as well as for youth innovation centres [3] or for different festivals of makers [4].

The machining center development works were carried out with the support of the FASIE, Contract No. 422GRNTIS5 / 44715. The authors express their sincere gratitude to the Department of Entrepreneurship and Innovative Development of the City of Moscow and the Ministry of Economic Development of the Russian Federation (Agreement No. 8 / 3-63in16 of $08 / 22 / 16$ ) for their invaluable assistance. 
С помощью станка с автосменой инструмента АТС "Индустрия 4.0" (рис.4) создание прототипа изделия или готового продукта значительно упрощается и к тому же минимизируется ручной труд [1, 2]. Станок подходит как для производственных нужд, так и для образовательных целей, например, в центрах молодежного инновационного творчества [3] или на различных фестивалях мейкеров [4].

Работы по изготовлению обрабатывающего центра выполнены при поддержке Фонда содействия инновациям (договор № 422ГРНТИС5/44715). Авторы выражают искреннюю благодарность Департаменту предпринимательства и инновационного развития города Москвы и Министерству экономического развития Российской Федерации (договор № 8/3-63ин-16 от 22 августа 2016 г.) за неоценимую помощь.

\section{ЛИТЕPATУPA / REFERENCES}

1. Akhmetova A., Belov Yu., Meshkov G., Yaminsky I. 3D positioning systems in the precise processing of materials. NANOINDUSTRY, 71 (1): 102-104, 2017.

2. Yaminsky I.V. Ideas and innovation, factories and plants. Nanoindustry, 1 (80): 84-86, 2018.

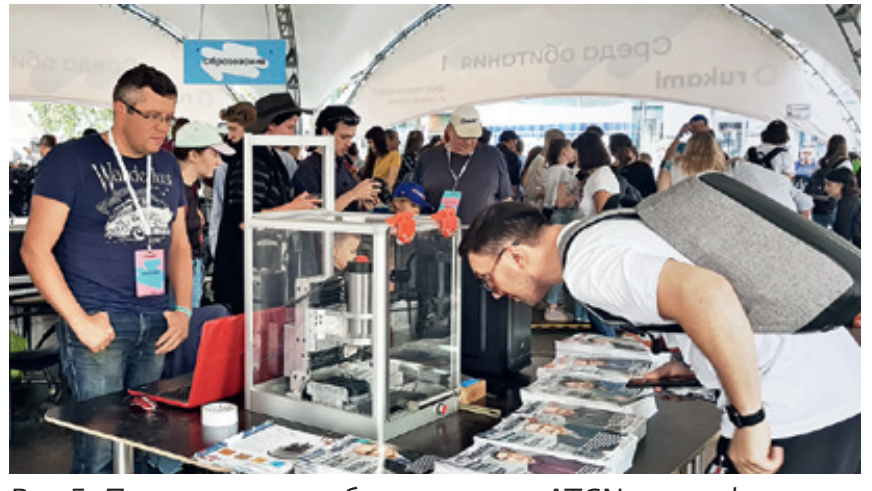

Puc.5. Презентация работы станка ATCNano на фестиваne Rukami

Fig.5. Presentation of ATCNano machinery operation at the Rukami festival

3. Akhmetova A.I., Fedoseev A.I., Yaminsky I.V., Belov Yu.K. Youth Innovation Creativity Center "Nanotechnology" at the Physics Department of Lomonosov Moscow State University. NANOINDUSTRY, 3 (83): 274-277, 2018.

4. Akhmetova A.I., Belov Yu.K., Yaminsky I.V. Open Innovations and the Science Festival. NANOINDUSTRY, 11 7-8 (86): 526-529, 2018.

\section{НОВЫЕ КНИГИ ИЗДАТЕЛЬСТВА «ТЕХНОСФЕРА»}

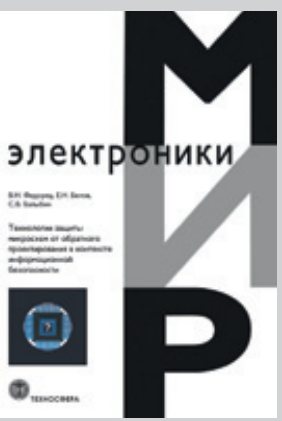

Цена 760 руб.

\section{ТЕХНОЛОГИИ ЗАЩИТЫ МИКРОСХЕМ ОТ ОБРАТНОГО ПРОЕКТИРОВАНИЯ В КОНТЕКСТЕ ИНФОРМАЦИОННОЙ БЕЗОПАСНОСТИ}

\section{В.Н.Федорец, Е.Н.Белов, С.В.Балыбин}

В книге рассмотрены вопросы обеспечения информационной безопасности современной электронной компонентной базы, используемой при разработке радиоэлектронной аппаратуры различного назначения. Особое внимание уделено вопросам уязвимости, возникающим при разработке и изготовлении микросхем, создаваемых по fabless-технологии.

Авторами рассмотрены инженерно-технические и организационно-методические решения по защите от обратного проектирования современных микросхем.

Книга может быть полезна специалистам в области микроэлектроники, разработчикам отечественной элементной базы, а также студентам, обучающимся по специальностям, связанным с разработкой микросистем и информационной безопасностью. 